\title{
ПУБЛИЧНОЕ УПРАВЛЕНИЕ ТРАНСФОРМАЦИОННЫМИ ПРОЦЕССАМИ В УКРАИНЕ И ПОЛЬШЕ: ПРОБЛЕМЫ И ПЕРСПЕКТИВЫ
}

\author{
Вацьковски К. С., Гордиенко Л. Ю.
}

\section{ВВЕДЕНИЕ}

Конец 80-х - начало 90-х годов XX века ознаменовался трансформационными изменениями политических систем на постсоветском пространстве, куда входили Польша и Украина. При этом Польша имела статус самостоятельного государства, а Украина входила в состав СССР как одна из его республик. Несмотря на различия в государственном устройстве как Польша, так и Украина избрали европейский путь развития. При этом как в польском государстве, так и украинском в качестве основной стратегии была избрана системная трансформация государственного устройства, базирующаяся на модернизационной парадигме.

Модернизационная парадигма, как отмечает Н.И. Лахижа ${ }^{1}$, сформировалась в середине XX века на основе процесса модернизации, который начался в Западной Европе в XVI-XVIII веках и распространился на весь мир благодаря экспансии Запада и особенному влиянию на этот процесс американской демократии.

Термин «модернизация» в переводе с английского означает «осовременивание» и применяется в тех случаях, когда речь идет об изменениях, усовершенствованиях, отвечающим современным требованиям ${ }^{2}$.

Если модернизация связана с изменениями, имеющими характер системных, коренных преобразований, то такое осовременивание правомерно отнести к трансформациям.

В сложившихся условиях происходит переосмысление основных категорий, моделей и инструментов управления, в том числе трансформационными процессами, протекающими как на национальном, региональном, межрегиональном, отраслевом, организационном и т.п. уровнях.

1 Лахижа М.І. Модернізація публічної адміністрації: теоретичні та практичні аспекти. Полтава : РВВ ПУСКУ, 2009. С. 9.

${ }^{2}$ Советский энциклопедический словарь. Москва : Советская энциклопедия, 1980. C. 828 . 
Требование эффективно функционировать в изменяющихся условиях и своевременно преобразовывать систему управления (государства, региона, отрасли и т.п.) к изменениям, носящим глобальный, национальный и тп. характер, вступает в противоречие с отсутствием соответствующей методологической базы и управленческого инструментария, обеспечивающего быструю реакцию субъекта управления, в частности публичных органов, на новые вызовы.

Поэтому целью исследования является попытка выявить проблемы и перспективы развития теоретических положений и практик публичного управления трансформационными процессами в Украине и Польше.

\section{1. Анализ современных проблем публичного управления} трансформационными процессами в Украине и Польше

Если рассматривать Украину как социально-экономическую систему, то с 1991 года по настоящее время происходит процесс внутренних трансформационных изменений в еe правовой, экономической, политической, социальной системах. Основной целью проводимых изменений, исходя из Стратегии устойчивого развития «Украина - 2020» ${ }^{3}$, является внедрение в Украине европейских стандартов жизни и выход Ураны на передовые позиции в мире. Для этого Стратегией устойчивого развития «Украина - 2020» предусмотрено 62 реформы и программы развития страны, которые целесообразно рассматривать как трансформационные проекты.

В марте 2017 года в рамках проекта Украинской ассоциации оценивания (УАО) «Усиление децентрализации в Украине» при финансовой поддержке национального фонда поддержки демократии (NED) CША был обнародован экспертный вывод о системе мониторинга и оценке Стратегии устойчивого развития «Украина $2020 »{ }^{4}$. В данном документе отмечается, что стратегические индикаторы реализации Стратегии (раздел 4 Стратегии) в большинстве своем отвечают минимальным требованиям, предъявляемым к оценке. В то же время оценить по этим показателям достижение цели Стратегии невозможно.

Экспертная оценка Стратегии устойчивого развития «Украина 2020» также показала, что стратегические индикаторы реализации Стратеги не использовались органами власти для оценки хода выполнения каких-либо реформ и программ, что свидетельствует об отсутствии трансформационных проектов на национальном уровне

3 Стратегія сталого розвитку «Україна-2020» Указ Президента України від 12 січня 2015 р. № 5/2015. URL : http://zakon2.rada.gov.ua/laws/show/5/2015 (дата звернення: 23.01.2018).

${ }^{4}$ Експертний висновок про систему моніторингу та оцінки Стратегії сталого розвитку «Україна-2020»: ukreval.org/.../Ekspertyza_Ukraina_2020_15.3.2017.pdf. (дата звернення: 23.01.2018). 
и неэффективной системе управления ними. Этот вывод подтверждает тот факт, что системы мониторинга и оценки, которые используется органами власти Украины, по мнению эксперта М.В. Савва ${ }^{5}$, не способны оценить выполнение Стратегии устойчивого развития «Украина - 2020». Кроме того, органы власти Украины практически не осуществляли в 2015-2016 годах и не осуществляют в настоящее время мониторинг и оценку Стратегии устойчивого развития «Украина - 2020», что привело к отсутствию размещения результатов мониторинга и оценивания в открытом доступе.

К очередному недостатку системы мониторинга и оценки Стратегии устойчивого развития «Украина-2020» эксперт М.В. Савва отнес отсутствие механизмов участия представителей гражданского общества в мониторинге и оценке этой Стратегии.

Приведенные выше факты свидетельствуют об отсутствии на общенациональном уровне управленческих механизмов разработки, внедрения и реализации трансформационных проектов, что приводит к неэффективности процесса достижения поставленных стратегических целей, а в некоторых случаях и барьером на пути их достижения.

Практика осуществления трансформационных процессов в Украине, которая обусловлена объективной необходимостью системных преобразований, как на общенациональном, так и региональном уровне имеет почти 30-летнюю историю, и связана с осуществлением трансформационных изменений, обусловленных политическими изменениями в стране (табл. 1).

Следует согласиться с мнением М. Кудрявцевой ${ }^{6}$, которая отмечает, что общей проблемой эффективного управления в Украине является то, что система публичного администрирования в украинском государстве не соответствует стратегическому курсу к демократии и европейским стандартам надлежащего управления. В такой системе составляющие ее элементы (институты управления) подвергаются постоянным изменениям в связи с перманентными конституционными изменениями, которые вызывают кардинальную трансформацию властных полномочий в государстве. В то же время, как справедливо подчеркивает этот же автор, взаимодействие субъектов публичного администрирования на сегодня характеризуется жестким политическим противостоянием, в то время как властный механизм государства должен учитывать, прежде всего, интегративный характер принципа разделения государственной власти. К сожалению, сейчас сама система публичного администрирования, вследствие исторически обусловленной неустойчивости, стала ограничивающим фактором политических и социальных реформ в украинском обществе.

${ }^{5}$ Там же

${ }^{6}$ Кудрявцева М. Перезавантаження влади як публічноуправлінський феномен: теоретико-методологічні засади. URL : www.dy.nayka.com.ua/pdf/3_2020/39.pdf (дата звернення: 07.12.2020). 
Таблица 1

Этапы трансформации политической системы Украины

\begin{tabular}{|c|c|}
\hline Этап & Содержание этапа \\
\hline 1 & 2 \\
\hline 1991-1996 гг. & $\begin{array}{l}\text { Формирование основных принципов нового общественного } \\
\text { устройства; осуществление трансформации Украины из составной } \\
\text { части бывшего Союза в самостоятельный организм с собственной } \\
\text { экономикой, финансово-денежной системой, властными } \\
\text { структурами, вооруженными силами, политическими и культурно-- } \\
\text { образовательными институтами, то есть всеми необходимыми } \\
\text { атрибутами государственности; заложены основы гражданского } \\
\text { общества с многопартийной системой; принята Конституция, } \\
\text { установившая президентско-парламентское устройство страны. } \\
\text { Этап политического романтизма }\end{array}$ \\
\hline 1996-1999 гг. & $\begin{array}{l}\text { Наличие противоречий между законодательной } \\
\text { и исполнительной ветвями власти, которые приобрели } \\
\text { перманентный характер и стали причиной того, что } \\
\text { законодательная власть не смогла создать целостной } \\
\text { и качественной правовой базы экономических и социальных } \\
\text { преобразований, а исполнительная - не обеспечила } \\
\text { достаточно эффективной реализации уже принятых законов }\end{array}$ \\
\hline 1999-2004 гг. & $\begin{array}{l}\text { Продолжение курса на демократические преобразования, } \\
\text { на европейский выбор; начата первая административная } \\
\text { реформа, инициированная вторым Президентом Украины. } \\
\text { Появление и разрушение парламентского большинства, } \\
\text { политический конфликт, правительственный кризис, } \\
\text { несинхронность политических и экономических реформ. } \\
\text { Отказ от парадигмы копирования, механического } \\
\text { и некритического заимствования зарубежного опыта. } \\
\text { Переход к политическому прагматизму }\end{array}$ \\
\hline 2004-2006 гг. & $\begin{array}{l}\text { Трансформационные изменения, обусловленные } \\
\text { политическими изменениями, вызванными глубоким } \\
\text { политическим кризисом, приведшим к «помаранчевой } \\
\text { революции» (ноябрь - декабрь } 2004 \text { г. - январь } 2005 \text { г. - } \\
\text { выборы третьего Президента Украины); новая редакция } \\
\text { Конституции Украины, установившая переход к парламентско- } \\
\text { президентскому устройству страны. Создание «антикризисной } \\
\text { колиции». Этап «всплеска» политического романтизма }\end{array}$ \\
\hline 2006-2010 гг. & $\begin{array}{l}\text { Наличие глубоких противоречий между законодательной } \\
\text { и исполнительной ветвями власти, приведший к роспуску } \\
\text { Верховной Рады Украины и досрочным парламентским } \\
\text { выборам, приведшим к формированию «демократической } \\
\text { колиции» и в последствии к ее распаду (сентябрь-октябрь } \\
2009 \text { г.). Период политической нестабильности, совпавший } \\
\text { с мировым финансово-экономическим кризисом. }\end{array}$ \\
\hline
\end{tabular}


Продовження таблиці 1

\begin{tabular}{|c|c|}
\hline 1 & 2 \\
\hline 2010-2013 гг. & $\begin{array}{l}\text { Отход от курса демократических преобразований; выборы } \\
\text { четвертого Президента Украины (февраль-март } 2010 \text { г.), } \\
\text { избравшего курс на узурпирование власти; возврат к редакции } \\
\text { Конституции } 1996 \text { г., устанавливающей президентско- } \\
\text { парламентскую форму правления; углубление политических } \\
\text { разногласий между властью и обществом, приведшее к } \\
\text { «революции достоинства», вызванной изменением курса } \\
\text { развития страны (ноябрь-декабрь } 2013 \text { г.). }\end{array}$ \\
\hline 2014-2019 гг. & $\begin{array}{l}\text { Досрочные выборы пятого Президента Украины (май } 2014 \text { г.), } \\
\text { а также Верховной Рады Украины (октябрь } 2014 \text { г.) как результат } \\
\text { «революции достоинства»; возврат к европейскому курсу развития } \\
\text { Украины, парламентско-президентской форме правления; } \\
\text { подписание соглашения об ассоциации между Украиной и ЕС, } \\
\text { которое вступило в силу 01.09.2017 года; безвизовый режим с } \\
\text { Европой (вступил в силу } 11.06 .2017 \text { г.); провозглашение } \\
\text { множества реформ во всех сферах жизнедеятельности общества и } \\
\text { начало их осуществления без системного подхода; начало } \\
\text { антитеррористической операции (апрель } 2014 \text { г.), в результате чего } \\
\text { Украина потеряла часть Донецкой и Луганской области; аннексия } \\
\text { Российской Федерацией Автономной Республики Крым (март } \\
2014 \text { г.). Период политической нестабильности и глубокого } \\
\text { Экономического кризиса, приведших к социальному кризису } \\
\text { и формированию системного кризиса с угрозой потери } \\
\text { государственности }\end{array}$ \\
\hline 2019 - н.в. & $\begin{array}{l}\text { Очередные выборы шестого президента Украины (апрель } \\
2019 \text { г.)., досрочные выборы в Верховную Раду Украины } \\
\text { (июль } 2020 \text { г.), выборы в органы местного самоуправления, } \\
\text { в том числе в новые органы - объединенные территориальные } \\
\text { громады (октябрь } 2020 \text { г.). Заявления власти о трансформации } \\
\text { в системе публичного управления в } 2019 \text { г., на продолжение } \\
\text { модерного публично-управленческого тренда на } \\
\text { институциональные изменения, на изменение парадигмы } \\
\text { управления, формирование принципиально новых подходов } \\
\text { реализации властных функций, перераспределение полномочий } \\
\text { между уровнями управления. В то же время наблюдается } \\
\text { продолжение конфликта на части Донецкой и Луганской } \\
\text { области; аннексии Российской Федерацией Автономной } \\
\text { Республики Крым. Реализация реформ, начатых в каденцию } \\
\text { пятого Президента Украины, усиление системного кризиса } \\
\text { пандемией СОVID 19, несистемное осуществление } \\
\text { институциональных преобразований, что приводит к принятию } \\
\text { управленческих решений без учета комплексного подхода } \\
\text { и неэффективности управления трансформационными } \\
\text { процессами в условиях системных коренных изменений как } \\
\text { на макро-, так и микро-уровнях. }\end{array}$ \\
\hline
\end{tabular}

Источник: собственная разработка 
В Польше системные трансформации берут свое начало с политических преобразований 1989 года (свободных демократических выборов), которые положили начало реформирования государства и построения развитого местного самоуправления.

Основными направлениями трансформационных изменений, которые были начаты в Польше еще в 80-х годах XX века, были развитие рыночной экономики, создание гражданского общества и демократизация. Как отмечает Л. К. Гилейко ${ }^{7}$, системная трансформация была не только необходима, но стала эффективной. Польша на переломе XX и XXI века принципиально иная, нежели с начала институциональной трансформации. По сравнению с другими государствами, особенно с теми, которые вместе с Польшей вошли в 2004 году в ЕС, Польша занимает очень хорошую позицию, о чем свидетельствуют данные, касающиеся успехов в приватизации, создании рыночной инфраструктуры, экономического роста, особенно развития предпринима-тельства.

Следует отметить, что реформа территориального устройства Республики Польша была относительно хорошо подготовлена в $1997-$ 1998 гг. и эффективно внедрена с 1 января 1999 года, результатом которой стала трехступенчатая структура административного устройства: органы самоуправления на уровне воеводств, районов и гмин. В 2004 году процесс реформ был закончен принятием законов о финансировании воеводских и региональных структур.

Основной целью административной реформы в Республики Польша, прежде всего, было: приблизить власть к человеку, создать органы самоуправления по образцу западноевропейских стран и усовершенствовать управление на местах таким образом, чтобы обычный гражданин не тратил много времени на решение своих повседневных проблем, а власть всегда находилась рядом.

Следующим шагом на пути реформ - создание органов самоуправления в воеводствах. В результате их количество уменьшилось с 49 до 16. Города, которые лишились статуса воеводских, стали городскими районами, или городами на правах района. В результате возникло 65 городских районов, 314 земских районов и 2489 гмин.

Реформы в Польше проходили в несколько этапов, каждый из которых осуществлялся на основе системы стратегий, которая была сформирована на базе европейских стратегических подходов.

7 Gilejko L.K. Polska transformacja - Proba bilansu i nowa perspektywa: www.kulturaswiecka.pl/node/77 (data wejścia: 23.03.2016). 
На современном этапе Польша реализовывает стратегию развития страны $2020^{8}$, которая в 2016 году была изменена с учетом нового видения развития страны, результатом чего явился новый стратегический документ «Стратегия ответственного развития до 2020 года (с перспективой до 2030 г.)», принятый Советом министров Польши 14 февраля $2017^{9}$.

Стратегия ответственного развития стала комплексным ответом, как на предыдущие ошибки трансформации, так и на новые вызовы, которые стоят перед социально-экономической политикой современного государства. Польское правительство на основе опыта реализации предыдущих вариантов национальной стратегии развития осуществило трансформационные изменения парадигмы развития с ориентацией на укрепление и модернизацию польской экономики с тем, чтобы занять одно из ведущих мест на основе повышения конкурентоспособности изделий и услуг, предлагаемых польскими фирмами.

Успешная системная трансформация в Республике Польша подтверждается прогнозом макроэкономического развития стран ЕС за 2020 год, обнародованным Еврокомиссией. Брюссель прогнозирует, что в 2020 году меньше «упадет» экономика Польши - примерно на 4,6\%. Это должен быть лучший показатель в Евросоюзе, где только в еврозоне среднее падение уровня ВВП может достичь $8,7 \%{ }^{10}$.

Интересно, что после предыдущего мирового экономического кризиса 2008 года Польша была единственной страной ЕС, которая зафиксировала небольшой рост ВВП - 1,8\% уже в следующем году, отмечается там же.

Положительные прогнозы для ВВП Польши в 2020 году объясняются несколькими факторами.

Во-первых, Польша имеет диверсифицированную экономику. Она не зависит от какого-то одного сектора, который бы генерировал львиную долю ВВП, например, автомобилестроение в Чехии и Словакии. Польша также не столь зависима от экспорта, как Германия или страны Вышеградской четверки.

8 Strategia Rozwoju Kraju 2020. URL : https://www.mir.gov.pl/strony/zadania/ polityka-rozwoju-kraju/zarzadzanie-rozwojem-kraju/strategia-rozwoju-kraju/ (data wejścia: 20.04.2017).

${ }^{9}$ Strategia Na Rzecz Odpowiedzialnego Rozwoju do roku 2020 (z perspektywa do 2030 r.). URL : htpp://www.SOR_2017_maly_internet_14022017_wstePMM-1.pdf. (data wejści: 20.04.2017).

10 Укрінформ від 15.11.2020. URL : https://www.ukrinform.ua/rubricworld/3060150-ekonomicnij-uspih-polsi-v-dobu-koronakrizi.html (дата звернення: 15.11.2020). 
Во-вторых, Польша является большой страной со значительным внутренним рынком, что значительно стабилизирует польскую экономику. Уровень потребления 38-миллионной страны, несколько снизился в апреле-мае, а к концу 2020 года снова начинает динамично расти.

B-третьих, Польша в последнее время начала экспортировать много цифровых услуг - в юридической, бухгалтерской, IT-сфере. Эти услуги и до коронакризиса (COVID 19) в значительной мере предоставлялись дистанционно, а после локдауна в Европе в 2020 году - спрос на них еще больше возрос. После начала пандемии страны начали вводить пакеты помощи бизнесу и населению, что увеличило потребность в бухгалтерской деятельности, оказании юридической помощи и IT-обслуживании, которые часто дистанционно предоставлялись из Польши.

Особенностью польской трансформации сферы публичного управления является то, что Польша является по европейским стандартам большой страной, в которой значительную роль продолжает играть традиционная промышленность, а также уровень общественной диверсификации. В то же время в отличие от Украины трансформационные процессы, как на национальном, так и региональном и местном уровне управления в Польше проводились системно соответственно разработанным стратегиям и парадигме стратегического управления, предполагающей своевременную реакцию на изменения во внешней среде путем принятия управленческих решений без коренных изменений намеченного курса.

\section{2. Направления и тенденции развития публичного управления} трансформационными процессами в Украине и Польше

В Украине в настоящее время, несмотря на пандемию (COVID 19), не отказались от реформ, начатых во многих сферах жизнедеятельности общества (медицине, образовании, местном самоуправлении и т.п.). Причем, как на предыдущем этапе трансформации политической системы Украины (табл. 1), эти реформы осуществляются не системно, без наличия стратегии развития страны.

В то же время, как отмечает О.А. Решота ${ }^{11}$, глобализационные вызовы современности и общественные преобразования в Украине требуют углубления и интенсификации процессов трансформации публичного управления в Украине на основе принципов демократичности, прозрачности, подотчетности и подконтрольности системы публичного управления гражданскому обществу.

${ }^{11}$ Решота О.А. Особливості розвитку публічного управління в Україні: сучасні тенденції та проблеми. URL : www.dy.nayka.com.ua/pdf/3_2020/39.pdf (дата звернення: 07.12.2020). 
Несмотря на несистемность трансформации публичного управления в Украине в трансформационных процессах отечественного публичного управления, можно проследить определенные тенденции и направления изменений к европеизации публичного управления, децентрализации власти, внедрения принципов демократического управления и нового публичного управления.

Следует отметить, что трансформация сфер жизнедеятельности украинского общества, которая осуществляется в форме реформ, с точки системного подхода и теории публичного управления, должна осуществляться системой органов публичного управления, которая в настоящее время находятся также в состоянии реформирования. Необходимо подчеркнуть, что в системе публичного управления современного государства трансформационные изменения системы органов управления должны осуществляться с учетом трендов, которые наблюдаются в самой системе публичного управления обществом, а также ее составляющих, и за ее пределами, то есть во внешней по отношению к ней среде.

Так, О.А. Решота группирует современные тенденции развития системы публичного управления в Украине в зависимости от ее составляющих, а именно: тенденции к изменениям субъектов управленческой деятельности в публичном управлении; тенденции к изменению объектов управления; к изменению целей публичного управления; тенденции к изменению управленческих связей; к изменению ценностных ориентаций в публичном управлении; тенденции к изменению концепций и теоретических подходов к публичному управлению; тенденции к европеизации системы публичного управления; тенденции к использованию новейших технологий в управленческом процессе, электронного управления и др.

Анализируя тенденции к изменениям субъектов управления стоит отметить, что на сегодня наблюдается, с одной стороны, провозглашение центральной властью ускорения процесса ее демократизации, использования партнерских подходов в принятии решений, развития и диверсификации форм и методов взаимодействия с населением, содействие усилению ее открытости, участия в ней граждан, применения партисипативных методов взаимодействия с гражданами с целью их привлечения к участию в принятии решений. С другой стороны, с 2019 г. на центральном уровне публичного управления президентская партия образовала монобольшинство в Верховной Раде Украины, не предоставив ни одного комитета оппозиции, тем самым сформировалась тенденция на централизацию.

На региональном и местном уровне управления наблюдаются процессы децентрализации, которые усиливают местную власть, что 
проявилось в процессе выборов в органы местного самоуправления в октябре 2020 года. Трансформационные процессы, связанные с децентрализацией, имеют тенденцию уменьшения влияния центральной власти на регионы. В то же время наблюдается тенденция к уменьшению коммуникаций между центральной и местной властью, что отрицательно сказывается на эффективности имплементации управленческих решений, принимаемых на центральном уровне.

Считаем, что на современном этапе развития государства должно происходит изменение системы публичного управления от бюрократического патернализма в представительство территориальных общин и активного привлечения негосударственных организаций. Важное значение должно приобретать широкое привлечение к функционированию публичного управления представителей неправительственных организаций, бизнес-структур, групп давления и гражданского общества в целом, а также применение в процессах государственного управления новейших концепций публичного управления, в частности концепций «активного государства», «демократического управления», «нового публичного управления», «публичного менеджмента» и др.

На практике реализация принципов новейших концепций публичного управления не наблюдается, что проявляется в тенденции центральной власти не учитывать влияния на публичное управление гражданского общества, начиная от недооценки гражданского общества или патерналистского к нему отношения со стороны государства и его органов, к уменьшению налаживания с ним многосторонних связей на основе партнерства и сотрудничества в различных сферах общественных отношений. Проявлением этого выступает тенденция практического отсутствия вовлечения в процессы государственного управления большого количества ученых, бизнесменов, деятелей общественных организаций в качестве консультантов, аналитиков и советников.

Тенденции к изменениям объектов публичного управления прослеживаются в проблемах ограниченности ресурсов; структурных изменениях общественного производства, проявляющихся в переходе Украины от индустриально развитой страны к экономике, базирующейся на аграрном секторе; к переходу на экономику потребления, в том числе различных видов услуг (в сфере медицины, образования, публичного администрирования и т.п.). В то же время наблюдается тенденция неэффективного перераспределения власти между центральными органами публичного управления и органами местного самоуправления вследствие отсутствия системности в проведении реформы децентрализации. По сравнению с Республикой 
Польша, которая успешно провела административную реформу, в Украине трансформационные изменения коснулись районного и местного уровня без проведения полноценной административнотерриториальной реформы и внесения соответствующих изменений в Конституцию.

В последние годы в системе публичного управления Украины наблюдается тенденция к образованию «ножниц» между кадровым обеспечением системы органов исполнительной власти, особенно на высшем уровне государственного управления, и не привлечению в органы исполнительной власти на высшем уровне управления выпускников, которых готовит Академия государственного управления при Президенте Украины и ее региональные институты (в городах: Днепр, Львов Одесса, Харьков), а также 129 высших учебных заведений Украины по магистерской программе соискателей высшего образования (281) «Публичное управление и администрирование».

В 2019 процесс реформирования государственного (публичного) управления актуализировал задачу сочетания общих процессов оптимизации деятельности органов публичной власти, совершенствования института публичной службы, формирования новой концепции государственной региональной политики в соответствии с концепцией децентрализации управленческих отношений. Такой подход к реформированию (перезагрузке) власти потребовал, как отмечает М. Кудрявцева ${ }^{12}$, значительных конституционных изменений, принятия новых законодательных актов, фактически формирования нового управленческого мировоззрения. В то же время сохранение старой бюрократической системы без ее коренной трансформации обусловливает деформацию самой идеи перезагрузки публичной власти.

С целью перезагрузки публичной власти Верховной радой Украины в 2019 году был принят Закон Украины «О внесении изменений в некоторые законы Украины относительно перезагрузки власти» ${ }^{13}$, который направлен на упрощение порядка принятия на государственную службу и освобождение от нее, повышение ответственности государственных служащих за результаты деятельности, внедрение возможности контрактной государственной службы и регулирования проблемных вопросов, обусловленных практическим внедрением

${ }^{12}$ Кудрявцева М. Перезавантаження влади як публічно-управлінський феномен: теоретико-методологічні засади. URL : www.dy.nayka.com.ua/pdf/3_ 2020/39.pdf (дата звернення: 07.12.2020).

${ }^{13}$ Про внесення змін до деяких законів України щодо перезавантаження влади : Закон України від 19 верес. 2019 р. № 117-IX. URL : https://zakon.rada.gov.ua/laws/ show/117-20 (дата звернення: 07.12.2020). 
закона, устранения избыточного (в пределах закона) регулирования соответствующих общественных отношений.

Следует согласиться с мнением М. Кудрявцевой, что целеполагание является ключевым фактором процесса перезагрузки власти, а важным показателем становится общественная идентичность власти, которая может быть определена через комплекс показателей публичноуправленческой деятельности: способность реагировать на внешние вызовы; способность программировать свою деятельность в кратко-, средне- и долгосрочной перспективе; способность отвечать на внешние и внутренние вызовы.

Несмотря на законодательное обеспечение трансформации публичной власти, практически современное публичное управление Украины, которое провозгласило базироваться на принципах унитарности государства и целостности ее территории, не смогло обеспечить сбалансированность социально-экономического развития регионов на основе их исторических, экономических, экологических, географических особенностей, культурных традиций, отвечать вызовам мирового развития.

Положительной тенденцией развития публичного управления в Украине является цифровая трансформация, обеспечивающая использование современных информационных технологий в системе публичного управления; внедрение электронного управления в деятельности органов публичной власти. Прогрессивные изменения можно наблюдать как на общегосударственном, так и на региональном уровне. Так, на центральном уровне публичного управления в 2019 году создано Министерство цифровой трансформации, основной задачей которого является формирование и реализация государственной политики в сфере цифровизации, цифровой экономики, цифровых инноваций, электронного управления и электронной демократии, развития информационного общества.

В настоящее время в Польше, как подчеркивает М. Касиньски ${ }^{14}$, говорят об изменении концепции государственного управления: переход от понимания его как государственной власти к концепции «государственная служба» и изменение ее фундаментальной роли, которая должна быть не столько бюрократическим управлением, сколько полностью основанной на управлении по другим правилам. Поэтому большее значение, чем раньше, придается неправовым: экономическим, политическим, организационным детерминантам администрирования. Распространяется новый образ администрации, в котором ее действия

${ }^{14}$ Kasiński M. Współczesne problemy rozwoju administracji publicznej w Polsce. Annales. Etyka w życiu gospodarczym. 2011. Vol. 14, Nr 1. S. 215-226. 
лишь в малой степени юридически определены, хотя формально все еще связаны конституционным требованием соблюдать общеобязательные правила. Можно наблюдать в этом тенденцию ослабления правовых связей, затрудняющих государственное управление, как угрозу самой сути правового государства, как временное явление, очередной повторяющейся волной приписывания деятельности администрации характера «свободной творческой деятельности в соответствии с уставами».

В настоящее время в государственном управлении Польши наблюдается тенденция к изменениям по следующим направлениям:

1) на экономизацию государственного управления;

2) на развитие гражданского участия в государственном управлении;

3) на дерегулирование - понимаемое как ограничение объема и/ или изменение способа правового регулирования деятельности государственных органов, а также ее характера ${ }^{15}$;

4) на европеизацию.

Тенденция на экономизацию государственного управления согласно различным концепциям трактуется следующим образом: от государственного менеджмента к публичному выбору, а также Новый публичный менеджмент (НПМ) как необходимость согласования деятельности административных органов по управлению предприятиями и ограничению их роли в защите рынка и предоставлении только тех услуг, которых рынок не может предоставить, но с использованием методов и технологий, взятых из частного сектора.

Тенденция на развитие гражданского участия в государственном управлении означает участие в процессах принятия управленческих решений в органах государственного управления потенциальных адресатов их деятельности. При этом, как отмечает Д. Р. Кийовски ${ }^{16}$ гражданское участие связано с идеей гражданского общества, консенсуса и социального диалога. Его можно понимать очень широко - как все проявления организации (объединения) людей, стремящихся достичь общих целей (включая удовлетворение их материальных и нематериальных потребностей), или более узко - как привлечение населения, а также созданных ими организаций в процесс реализации публичных задач государственными или местными органами власти.

${ }^{15}$ Stefaniuk M. Działanie administracji publicznej $w$ ujęciu nauk administracyjnych. Wydawnictwo UMCS, Lublin 2009. URL : http://www.annalesonline.uni.lodz.pl/ archiwum/2011/2011_01_kasinski_215_226.pdf (data wejścia: 07.12.2020).

16 Kijowski D.R. Partycypacja obywatelska w samorządowych procesach decyzyjnych - zagadnienia ogólne.

Samorzad Terytorialny. 2010. Nr. 1-2. S. 9. 
Тенденция дерегулирования означает ограничение или изменение характера вмешательства законодателя в деятельности администрации. Это проявляется как:

1) применение норм, отличных от административных и юридических;

2) ограничение спектра или исключение правового регулирования определенной области социальной или экономической жизни в целом.

Дерегулирование на современном этапе рассматривается как явление, позволяющее администрации действовать гибко, но соответственно принципам демократического правового государства.

Тенденция европеизации, если принять во внимание мнение М. Касински, можно понимать по-разному. В частности, по отношению к европеизации административного права и государственного управления эта тенденция может рассматриваться как элемент процессов глобализации или как отдельный процесс. Первый подход означает принятие моделей модернизации, разработанных в неевропейских административных системах, особенно англосаксонских. Второй основан на признании того, что модернизация государственного управления должна основываться главным образом на европейских традициях и опыте, и только ограниченное использование неевропейских программ (американских), хотя некоторые постулаты совпадают, например, усиление принципа субсидиарности, примат территориальной системы над отраслевой, ограничение свободы принятия решений, доступ к публичной информации, горизонтальные сети вместо иерархических, социальный диалог и гражданское участие в управлении, этические стандарты чиновников.

В Польше общепринят второй подход - признание роли конкретной европейской традиции в формировании континентальных моделей государственного управления и необходимости изменений в польском государственном управлении в связи с процессом европейской интеграции.

Такой подход на практике, в частности, можно проиллюстрировать на примере разработки системы стратегий развития Польши, в основу которого положена европейская концепция стратегического управления.

Таким образом, в Польше в последние годы создана комплексная система управления развитием страны, опирающаяся на политику, в основу которой положены такие стратегические документы, как:

- долгосрочная стратегия развития страны (ДСРС) - Польша 2030, в которой указаны основные тренды, вызовы и концепции развития 
страны на долгосрочную перспективу (принята Советом Министров Польши 05.02.2013 г. $)^{17}$;

- среднесрочная стратегия развития страны - ССРС 2020 (принята Советом Министров Польши 25.09.2012г. $)^{18}$, в которой определены стратегические цели развития страны до 2020 г., являющиеся ключевыми для определения действий по развитию, в том числе возможности по финансированию в рамках будущей финансовой перспективы ЕС на 2014-2020 гг.;

- девять интегрированных внесекторных стратегий, служащих реализации заложенных целей развития:

1) стратегия инновационности и эффективности экономики Динамичная Польша 2020;

2) стратегия развития человеческого капитала;

3) стратегия развития транспорта до 2020 года (с перспективой до 2030 года);

4) стратегия безопасности энергетической и окружающей среды;

5) стратегия «Эффективное государство»;

6) стратегия развития общественного капитала;

7) стратегия развития системы государственной безопасности;

8) государственная стратегия регионального развития 2010-2020;

9) стратегия равномерного развития деревни, сельского хозяйства и рыболовства.

Указанные виды стратегий объединяет общая иерархия целей и направлений.

Польше удалось согласовать цели ЕС 2020 с целями ССРС 2020, а также связанными с ними интегрированные цели, что было сделано благодаря синхронизации во времени стратегических работ на уровне страны и $\mathrm{EC}^{19}$.

Пять целей ССРС 2020, вытекающие непосредственно из Стратегии EC 2020, касаются: повышения трудоустройства, роста инновационности (измеряемого ростом средств на $\mathrm{B}+\mathrm{R}$ в целом и ростом доли расходов предприятий), уменьшения выброса газов теплоэлектростанций и увеличения обновляемой энергии в общем расходовании энергии, повышения уровня образования и поддержки общественного подключения. Остальные цели ССРС 2020,

\footnotetext{
${ }^{17}$ Polska 2030. Trzecia fala nowoczesnosci. Dlugookresowa Strategia Rozwoju Kraju. URL : http://www.mac.gov.pl (data wejścia: 07.12.2020).

18 Strategia Rozwoju Kraju 2020. URL : http://www.mir.gov.pl (data wejścia: 07.12.2020).

${ }^{19}$ Programowanie perspektywy finansowej 2014 - 2020 - Umowa Partnerstwa. W-wa : MIiR, 2014. $246 \mathrm{~s}$.
} 
вытекающие из специфики страны, в процессе их реализации также учитывали Стратегию ЕС 2020.

Особенно важно осуществление системных, компетентностных и институциональных изменений, содействующих освобождению потенциалов и резервов развития, а также финансовых средств.

Среднесрочная стратегия развития Польши 2020 направлена не только на публичную администрацию. Она интегрирует вокруг стратегических целей все публичные субъекты, а также общественные и экономические сферы, которые участвуют в процессах развития и могут ее поддерживать как на центральном, так и региональном уровнях.

Кроме среднесрочной стратегии развития «Польша 2020», а также долгосрочной стратегии «Польша 2030», основываясь на инструментах стратегического менеджмента разработана стратегическая модель «Польша 2050» ${ }^{20}$, которая пытается представить общество, основанное на современной цивилизации, связанное европейскими или, в более широком смысле, евроатлантическими традициями, с точки зрения нескольких основных характеристик или отличительных черт, которые можно сгруппировать в три основных канона: институты, образование в широком смысле слова и культурная система.

К 2050 году Польша должна развиться в экономически сильную страну с крупным экспортом высоких технологий и развитой коммуникационной инфраструктурой, с высокообразованным населением и преобладанием относительно стабильной занятости, и с сильными демократическими институтами.

\section{ВЫВОДЫ}

В современном публичном управлении, как в органах государственной исполнительной власти, так и местного самоуправления, в частности под влиянием пандемии COVID 19, возникли проблемы, решение которых требуют системного и инновационного подхода.

В результате данного исследования в Украине к таким проблемам было отнесено отсутствие на общенациональном уровне управленческих механизмов разработки, внедрения и реализации трансформационных проектов, что приводит к неэффективности процесса достижения поставленных стратегических целей, а в некоторых случаях и барьером на пути их достижения. Сама система публичного администрирования, вследствие исторически обусловленной неустойчивости, стала ограничивающим фактором политических и социальных реформ в украинском обществе.

20 "Poland 2050": Report. W-wa : PAN WDN, 2011. 116 p. 
В Украине, несмотря на несистемность трансформации публичного управления, можно проследить определенные тенденции и направления изменений к европеизации публичного управления, децентрализации власти, внедрения принципов демократического управления и нового публичного менеджмента.

По сравнению с Республикой Польша, которая успешно провела административную реформу, в Украине трансформационные изменения коснулись районного и местного уровня без проведения полноценной административно-территориальной реформы и внесения соответствующих изменений в Конституцию.

Основными направлениями трансформационных изменений, которые были начаты в Польше еще в 80-х годах XX века, были развитие рыночной экономики, создание гражданского общества и демократизация. Тенденция осуществления стратегических трансформационных изменений на основе системы стратегий делает возможным к 2050 году Польшу сделать экономически сильной страной с крупным экспортом высоких технологий и развитой коммуникационной инфраструктурой, с высокообразованным населением и преобладанием относительно стабильной занятости, и с сильными демократическими институтами.

\section{АННОТАЦИЯ}

Статья посвящена исследованию проблем и тенденций публичного управления трансформационными процессами в Украине и Польше. Исследованы основные проблемы трансформации политической системы Украины с учетом хронологии ее развития. Проанализированы проблемы публичного управления трансформационными процессами в Украине. Выделены направления и тенденции развития публичного управления трансформационными процессами в Украине, носящие отрицательный и положительный характер.

Исследование проблем публичного управления трансформационными процессами в Польше обосновало гипотезу об эффективности управленческого механизма их разрешения, что подтвердилось приведенными в статье статистическими данными. Приведены основные направления и тенденции развития публичного трансформационными процессами в Польше, осуществляемые на основе системного и инновационного подхода с использованием инструментов стратегического менеджмента. Планируется к 2050 году Польшу сделать экономически сильной страной с крупным экспортом высоких технологий и развитой коммуникационной инфраструктурой, с высокообразованным населением и преобладанием относительно стабильной занятости, сильными демократическими институтами. 


\section{ЛИТЕРАТУРА}

1. Лахижа M.I. Модернізація публічної адміністрації: теоретичні та практичні аспекти. Полтава : РВВ ПУСКУ, 2009. 289 с.

2. Советский энциклопедический словарь. Москва : Советская энциклопедия. $1980.1600 \mathrm{c}$.

3. Стратегія сталого розвитку «Україна-2020». Указ Президента України від 12 січня 2015 р. № 5/2015. URL : http://zakon2.rada.gov.ua/laws/show/5/2015 (дата звернення: 23.01.2018).

4. Експертний висновок про систему моніторингу та оцінки Стратегії сталого розвитку «Україна-2020». URL : ukreval.org/.../Ekspertyza_Ukraina_2020_15.3.2017.pdf. (дата звернення: 23.01.2018).

5. Кудрявцева М. Перезавантаження влади як публічноуправлінський феномен: теоретико-методологічні засади. URL : www.dy.nayka.com.ua/pdf/3_2020/39.pdf (дата звернення: 07.12.2020).

6. Gilejko L. K. Polska transformacja - Proba bilansu i nowa perspektywa. URL : www. kulturaswiecka.pl/node/77 (data wejścia: 23.03.2016).

7. Strategia Rozwoju Kraju 2020. URL https://www.mir.gov.pl/strony/zadania/ polityka-rozwoju-kraju/zarzadzanierozwojem -kraju/strategia-rozwoju-kraju/ (data wejścia: 20.04.2017).

8. Strategia Na Rzecz Odpowiedzialnego Rozwoju do roku 2020 (z perspektywa do 2030 r.). URL : htpp://www.SOR_2017_maly_internet_ 14022017_wstePMM-1.pdf. (data wejśca: 20.04.2017).

9. Укрінформ від 15.11.2020. URL : https://www.ukrinform.ua/rubricworld/3060150-ekonomicnij-uspih-polsi-v-dobu-koronakrizi.html (дата звернення: 15. 11.2020).

10. Решота О.А. Особливості розвитку публічного управління в Україні: сучасні тенденції та проблеми. URL www.dy.nayka.com.ua/pdf/3_2020/39.pdf (дата звернення: 07.12.2020).

11. Кудрявцева М. Перезавантаження влади як публічноуправлінський феномен: теоретико-методологічні засади. URL : www.dy.nayka.com.ua/pdf/3_2020/39.pdf (дата звернення: 07.12.2020).

12. Про внесення змін до деяких законів України щодо перезавантаження влади : Закон України від 19 верес. 2019 р. № 117-IX. URL : https://zakon.rada.gov.ua/ laws/ show/117-20 (дата звернення: 07.12.2020).

13. Kasiński M. Współczesne problemy rozwoju administracji publicznej w Polsce. Annales. Etyka w życiu gospodarczym. 2011. Vol. 14, $\mathrm{Nr} 1$. S. 215-226.

14. Stefaniuk M. Działanie administracji publicznej w ujęciu nauk administracyjnych. Wydawnictwo UMCS, Lublin 2009. URL : 
http://www.annalesonline.uni.lodz.pl/archiwum/2011/2011_01_kasinski_21 5_226.pdf (data wejścia: 07.12.2020).

15. Kijowski D.R. Partycypacja obywatelska w samorządowych procesach decyzyjnych - zagadnienia ogólne. Samorząd Terytorialny. 2010. Nr. 1-2. S. 9.

16. Polska 2030. Trzecia fala nowoczesnosci. Dlugookresowa Strategia Rozwoju Kraju. URL : http://www.mac.gov.pl (data wejścia: 07.12.2020).

17. Strategia Rozwoju Kraju 2020. URL : http://www.mir.gov.pl (data wejścia: 07.12.2020).

18. Programowanie perspektywy finansowej 2014-2020 - Umowa Partnerstwa. - W-wa : MIiR, 2014. 246 s.

19. "Poland 2050": Report. - W-wa : PAN WDN, 2011. 116 p.

\section{Information about the authors:}

Wackowski K. S.,

Doctor of Economic Sciences,

Head of the Department of IT Systems Warsaw University of Technology "Warsaw Polytechnic" 86, Narbutta str., Warszawa, 02-524, Poland

Gordiienko L. Yu.,

Candidate of Economic Sciences, Associate Professor at the Department of State Administration, Public Administration and Regional Economics Simon Kuznets Kharkiv National University of Economics 9-A, Science avenue, Kharkiv, 61166, Ukraine 